\title{
XANTHONES FROM CELL CULTURES OF HYPERICUM GNIDIOIDES SEEM.
}

\author{
A. M. A. Abd El-Mawla
}

Department of Pharmacognosy, Faculty of Pharmacy, Assiut University, Assiut, Egypt

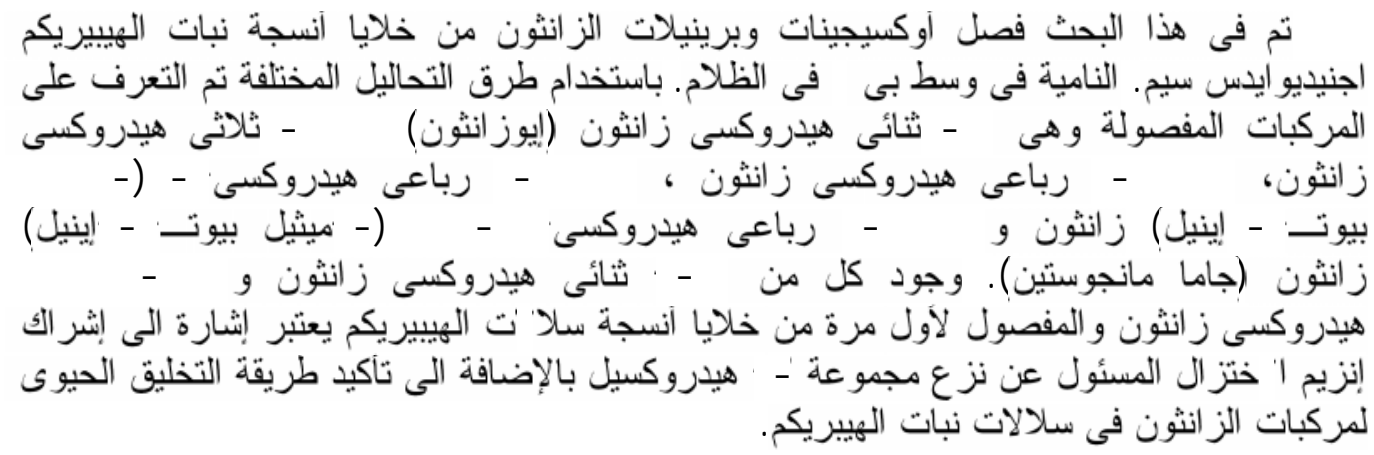

\begin{abstract}
Oxygenated and prenylated xanthones were isolated from the cell cultures of Hypericum gnidioides Seem. when grown in modified B5 medium in the dark. Based on the spectral methods, the structure of the isolated compounds were elucidated as 1,7-dihydroxyxanthone (euxanthone), 1,3,7-trihydroxyxanthone, 1,3,5,6-tetrahydroxyxanthone, 1,3,6,7-tetrahydroxy-8(3-methylbut-2-enyl) xanthone and 1,3,6,7-tetrahydroxy-2,8-di(3-methylbut-2-enyl) xanthone ( $\gamma$-mangostin). The occurrence of both 1,7-dihydroxyxanthone and 1,3,7-trihydroxyxanthone which is recorded for the first time in cell cultures of Hypericum species indicate the presence of a reductase activity responsible for eliminating the 3-hydroxy group and confirm the biosynthetic pathway of xanthones in Hypericum species respectively.
\end{abstract}

\section{INTRODUCTION}

Xanthone derivatives of various structural types have been isolated from several Hypericum species. ${ }^{1-3}$ Ethanolic extracts from Hypericum species (Hypericaceae) have been shown to exert marked effects on the central nervous system. ${ }^{4,5,6}$ Best one is that obtained from Hypericum perforatum which is widely used as an antidepressant drug. ${ }^{4}$ Interestingly, several xanthones from higher plants showed anti-fungal and broad spectrum antibacterial activity viz., mangostin and gartanin from Garcinia mangostana L. (Guttiferae). ${ }^{7}$ Similar properties have been reported for jacareubin and 6-deoxyjacareubin, two chromenoxanthones isolated from Callophyllum inophyllum L. (Guttiferae). ${ }^{8} 9$ Mangostin also exhibited significant anti-inflammatory properties. $^{10}$ 1,7-Dihydroxyxanthone, 1,3,7trihydroxyxanthone and 1,3,5,6-tetrahydroxy- xanthone have anti-inflammatory effect through the suppression of chemical mediators released from mast cell and neutrophil degranulation. ${ }^{11}$

Xanthones from Garcinia subelliptica were found to have anti-oxidative properties. ${ }^{12}$ A number of xanthones from Cansacora decussata and Garcinia mangostana exhibit significant tuberculostatic and anti-viral activities respectively. ${ }^{13,14}$ The dihydrofuranoxanthone epoxide psorospermin exhibit pronounced cytotoxicity and anti-tumour activity against lymphocytic leukemia and mammary and colon tumour systems. ${ }^{15}$

In the present work, the callus induction from the young shoots of Hypericum gnidioides Seem. and the isolation and structural elucidation of the xanthones known to be constituents present in Hypericaceae were carried out. 


\section{EXPERIMENTAL}

\section{Apparatus}

Melting points were determined on Koffler's heating stage microscope. UV spectra were carried out in Unicam SP-1750 Ultraviolet Spectrometer. IR spectra were determined in Unicam SP-1025 Infra Red Spectrometer. EI-MS spectra were performed on Hitachi M-80 and on MAT 311A, 70 ev. Spectrometer. ${ }^{1} \mathrm{H}-\mathrm{NMR}(500 \mathrm{MHz})$ spectra were performed in DMSO- $\mathrm{d}_{6}$ using TMS as internal standard. The TLC was performed on silica gel $60 \quad \mathrm{~F}_{254}$-coated aluminium sheets (Merck, Darmstadt, Germany). The preparative TLC was carried out on silica gel $60 \mathrm{~F}_{254^{-}}$ coated glass sheets.

\section{Plant material}

Hypericum gnidioides seeds were kindly identified and provided by Prof. Dr. L. Beerhues and Dr. Wagner Barillas, Institute for Pharmaceutical Biology, University of Bonn, Germany.

\section{Authentic reference xanthones}

The reference xanthones were obtained from Prof. Dr. L. Beerhues, Institute for Pharmaceutical Biology, Technical UniversityBraunschweig, Germany. To whom the author is greatly indebted.

\section{Cell cultures}

Callus cultures of Hypericum gnidioides Seem. were established from the young shoots of sterile germinated seeds. After surface sterilization, stem and leaf segments were placed on B5 solid medium ${ }^{16}$ (Table 1) supplemented with $2 \mathrm{~g} / \mathrm{l} \mathrm{NZ-Amine,} 2.0 \mathrm{mg} / \mathrm{l} 1$ naphthylacetic acid, $2.0 \mathrm{mg} / \mathrm{l}$ indole-3-acetic acid and $0.5 \mathrm{mg} / \mathrm{l}$ 6-(furfurylamino)-purine. The resulting callus tissue was transferred to the modified liquid B5 medium (without agar) and grown in the dark. Cultures $(50 \mathrm{ml})$ were shaken in 300-ml Erlenmeyer flasks at 100 r.p.m. and $25^{\circ}$.
Table 1: Composition of B5 medium. ${ }^{16}$

\begin{tabular}{|c|c|}
\hline Ingredients & $\begin{array}{l}\text { Amount used } \\
\text { (mg/l medium) }\end{array}$ \\
\hline $\mathrm{NaH}_{2} \mathrm{Po}_{4} \cdot \mathrm{H}_{2} \mathrm{O}$ & 150 \\
\hline $\mathrm{CaCl}_{2} \cdot 2 \mathrm{H}_{2} \mathrm{O}$ & 150 \\
\hline $\left.\mathrm{NH}_{4}\right)_{2} \mathrm{SO}_{4}$ & 134 \\
\hline $\mathrm{MgSO}_{4} \cdot 7 \mathrm{H}_{2} \mathrm{O}$ & 250 \\
\hline $\mathrm{KNO}_{3}$ & 2500 \\
\hline $\mathrm{FeSO}_{4} \cdot 7 \mathrm{H}_{2} \mathrm{O}$ & 25.6 \\
\hline $\mathrm{Na}_{2}$ EDTA. $2 \mathrm{H}_{2} \mathrm{O}$ & 34.27 \\
\hline & 0.75 \\
\hline $\mathrm{MnSO}_{4} \cdot \mathrm{H}_{2} \mathrm{O}$ & 10 \\
\hline $\mathrm{H}_{3} \mathrm{BO}_{3}$ & 3 \\
\hline $\mathrm{ZnSO}_{4} \cdot 7 \mathrm{H}_{2} \mathrm{O}$ & 3 \\
\hline $\mathrm{Na}_{2} \mathrm{MoO}_{4} \cdot 2 \mathrm{H}_{2} \mathrm{O}$ & 0.25 \\
\hline $\mathrm{CuSO}_{4} \cdot 5 \mathrm{H}_{2} \mathrm{O}$ & 0.025 \\
\hline $\mathrm{CoCl}_{2} \cdot 6 \mathrm{H}_{2} \mathrm{O}$ & 0.025 \\
\hline Nicotinic acid & 1 \\
\hline dichloride & 10 \\
\hline $\begin{array}{l}\text { Pyridoxal hydrochloride } \\
\text { myo-Inositol }\end{array}$ & $\begin{array}{c}1 \\
100\end{array}$ \\
\hline Hormone & \\
\hline 2,4-Dichlorophenoxyacetic acid & 1 \\
\hline \multicolumn{2}{|c|}{$\begin{array}{l}\text { Preparation: mix ingredients with about } \\
600 \mathrm{ml} \text { distilled water in a } 1 \text { liter glass } \\
\text { beaker, add and dissolve } 20 \mathrm{~g} / \mathrm{l} \text { sucrose. } \\
\text { Bring the solution up to } 1 \text { liter by adding } \\
\text { distilled water, then adjust the } \mathrm{pH} \text { to } 5.5 \mathrm{with} \\
\text { a concentrated KOH solution. Add } 7 \mathrm{~g} / 1 \\
\text { agar, place the beaker on the hot plate and } \\
\text { frequently stir the solution until the agar is } \\
\text { dissolved, divide the solution in } 300 \text {-ml } \\
\text { Erlenmeyer flasks each one with } 50 \mathrm{ml} \text {, keep } \\
\text { the cap close and sterilize at } 120^{\circ} \text { for } 20 \mathrm{~min} \\
\text { in autoclave. }\end{array}$} \\
\hline
\end{tabular}

\section{Extraction and isolation of xanthones Extraction of constituents}

Xanthones were extracted according to a published method. ${ }^{17}$ Cells (100 g) were ground in $700 \mathrm{ml}$ acetone and the homogenate was filtered. The residue was extracted twice with $500 \mathrm{ml}$ acetone. The acetone phases were combined and evaporated to dryness. The residue $(9 \mathrm{~g})$ was re-dissolved in $100 \mathrm{ml}$ methanol and subjected to TLC and HPLC analyses. 


\section{Isolation of xanthones}

The methanolic residue was subjected to thin layer chromatography (TLC) on silica gel $60 \quad \mathrm{~F}_{254}$-coated aluminium sheets (Merck, Darmstadt, Germany) using cyclohexane dichloromethane - ethylformate - formic acid (35: 30: 30: 1 by vol.) (system I) as a mobile phase revealed seven spots, five of them are majors, attained yellow colours with $1 \% \mathrm{w} / \mathrm{v}$ $\mathrm{AlCl}_{3}$ and were separated by preparative TLC on silica gel $60 \quad \mathrm{~F}_{254}$-coated glass sheets (Merck, Darmstadt, Germany) using the solvent system mentioned above to compounds 1-5. Further purification of compounds 1-5 was achieved by HPLC (L-6200 A intelligent pump, L-4000 UV detector, Merck Hitachi, Japan). This was performed on a reversed phase-(RP)-8 column (Nucleosile ${ }^{\circledR}$ 100-5; $25 \mathrm{~cm}$ long, 0.4 cm i.d.; Macherey-Nagel, Düren, Germany) using water (A) and methanol (B) as the solvents. The following gradient was employed: $35 \%$ B for 2 min, 35-70\% B within $20 \mathrm{~min}$, then isocratic elution at $70 \% \mathrm{~B}$. The flow rate was $1 \mathrm{ml} / \mathrm{min}$ and the detection wavelength set to $254 \mathrm{~nm}$.

1,7-Dihydroxyxanthone (euxanthone, compound 1, Fig. 1). $9 \mathrm{mg}(0.09 \mathrm{mg} / \mathrm{g}$ callus fresh weight), yellowish fine needles $\left(\mathrm{CH}_{3} \mathrm{OH}\right)$, mp $225-227^{\circ}, R_{f}=0.84$ (system I). It showed an orange-yellow fluorescence under UV light and a positive $\mathrm{FeCl}_{3}$ test. UV: $\lambda_{\max ,}\left(\mathrm{CH}_{3} \mathrm{OH}\right.$, nm) $236,258,287,311 \mathrm{sh}, 384 ; \lambda_{\max }\left(\mathrm{CH}_{3} \mathrm{OH}+\right.$ $\mathrm{NaOMe} n m) 238,262,291,342,422 ; \lambda_{\max }$ $\left(\mathrm{CH}_{3} \mathrm{OH}+\mathrm{NaOAc}, \mathrm{nm}\right) 235,258,287,310$, 384; $\lambda_{\max },\left(\mathrm{CH}_{3} \mathrm{OH}+\mathrm{NaOAc} / \mathrm{H}_{3} \mathrm{BO}_{3}, \mathrm{~nm}\right) 235$, $258,287,310,384 ; \lambda_{\max }\left(\mathrm{CH}_{3} \mathrm{OH}+\mathrm{AlCl}_{3}, \mathrm{~nm}\right)$ $234,273,285,348,433 ; \lambda_{\max }\left(\mathrm{CH}_{3} \mathrm{OH}+\right.$ $\left.\mathrm{AlCl}_{3} / \mathrm{HCl}, \mathrm{nm}\right) 235,272,284,346,433$. IR $v_{\max }(\mathrm{KBr}) \mathrm{cm}^{-1}: 3290(\mathrm{OH}), 1640(\mathrm{C}=\mathrm{O})$, $1590(\mathrm{C}=\mathrm{C}), 1300$ and $1090(\mathrm{C}-\mathrm{O}-\mathrm{C}$ stretching vibrations). EI-MS $(\mathrm{m} / \mathrm{z}): 228\left[\mathrm{M}^{+}\right] .{ }^{1} \mathrm{H}-\mathrm{NMR}$ $\left(500 \mathrm{MHz}, \mathrm{DMSO}-\mathrm{d}_{6}\right): \delta 12.53(1 \mathrm{H}, \mathrm{s}, \mathrm{OH}-$ C1), $7.70(1 \mathrm{H}, \mathrm{d}, \mathrm{J}=2.2 \mathrm{~Hz}, \mathrm{H}-8), 7.58(1 \mathrm{H}, \mathrm{t}$, $\mathrm{J}=8.1 \mathrm{~Hz}, \mathrm{H}-3), 7.45(1 \mathrm{H}, \mathrm{d}, \mathrm{J}=8.6 \mathrm{~Hz}, \mathrm{H}-5)$, $7.40(1 \mathrm{H}, \mathrm{dd}, \mathrm{J}=8.1$ and $1.8 \mathrm{~Hz}, \mathrm{H}-2), 7.30$ $(1 \mathrm{H}, \mathrm{dd}, \mathrm{J}=8.6$ and $2.2 \mathrm{~Hz}, \mathrm{H}-6), 6.94(1 \mathrm{H}, \mathrm{dd}$, $\mathrm{J}=8.1$ and $1.8 \mathrm{~Hz}, \mathrm{H}-4)$.

1,3,7-Trihydroxyxanthone (compound $\mathbf{2}$, Fig. 1). $4 \mathrm{mg}$ (0.04 mg/g callus fresh weight), yellow needles $\left(\mathrm{CH}_{3} \mathrm{OH}\right), \mathrm{mp} 214-216^{\circ}, \mathrm{R}_{\mathrm{f}}=$ 0.62 (system I). This compound gave an orange-yellow fluorescence under UV light and a positive $\mathrm{FeCl}_{3}$ test. $\mathrm{UV}$ : $\lambda_{\max }\left(\mathrm{CH}_{3} \mathrm{OH}, \mathrm{nm}\right)$
$240,262,310,375 ; \lambda_{\max }\left(\mathrm{CH}_{3} \mathrm{OH}+\mathrm{NaOMe}\right.$, nm) $245,266,340,410 ; \lambda_{\max }\left(\mathrm{CH}_{3} \mathrm{OH}+\right.$ $\mathrm{NaOAc}, \mathrm{nm}) 241,264,370,422 ; \lambda_{\max }\left(\mathrm{CH}_{3} \mathrm{OH}\right.$ $\left.+\mathrm{NaOAc} / \mathrm{H}_{3} \mathrm{BO}_{3}, \mathrm{~nm}\right) 240,263,371,422 ; \lambda_{\max }$ $\left(\mathrm{CH}_{3} \mathrm{OH}+\mathrm{AlCl}_{3}, \mathrm{~nm}\right) 241,270,356,435 ; \lambda_{\max }$ $\left(\mathrm{CH}_{3} \mathrm{OH}+\mathrm{AlCl}_{3} / \mathrm{HCl}, \mathrm{nm}\right) 239,268,354,435$. IR $v_{\max }(\mathrm{KBr}) \mathrm{cm}^{-1}: 3310(\mathrm{OH}), 1640(\mathrm{C}=\mathrm{O})$, $1600(\mathrm{C}=\mathrm{C}), 1270$ and 1130 (C-O-C stretching vibrations). EI-MS $(\mathrm{m} / \mathrm{z}): 244\left[\mathrm{M}^{+}\right] .{ }^{1} \mathrm{H}-\mathrm{NMR}$ $\left(500 \mathrm{MHz}, \mathrm{DMSO}-\mathrm{d}_{6}\right): \delta 12.71(1 \mathrm{H}, \mathrm{s}, \mathrm{OH}-$ C1), $7.48(1 \mathrm{H}, \mathrm{d}, \mathrm{J}=8.3 \mathrm{~Hz}, \mathrm{H}-5), 7.41(1 \mathrm{H}, \mathrm{d}$, $\mathrm{J}=2.3 \mathrm{~Hz}, \mathrm{H}-8), 7.22(1 \mathrm{H}, \mathrm{dd}, \mathrm{J}=8.3$ and 2.3 $\mathrm{Hz}, \mathrm{H}-6), 6.41(1 \mathrm{H}, \mathrm{d}, \mathrm{J}=2.1 \mathrm{~Hz}, \mathrm{H}-4), 6.21$ $(1 \mathrm{H}, \mathrm{d}, \mathrm{J}=2.1 \mathrm{~Hz}, \mathrm{H}-2)$.

1,3,5,6-Tetrahydroxyxanthone (compound 3, Fig. 1). $7 \mathrm{mg}(0.07 \mathrm{mg} / \mathrm{g}$ callus fresh weight), yellow needles $\left(\mathrm{CH}_{3} \mathrm{OH}\right), \mathrm{mp} 206$ $208^{\circ}, R_{\mathrm{f}}=0.37$ (system I). It gave a positive $\mathrm{FeCl}_{3}$ test and a yellow fluorescence under UV light. UV: $\lambda_{\max }\left(\mathrm{CH}_{3} \mathrm{OH}, \mathrm{nm}\right) 250,283 \mathrm{sh}, 326$; $\lambda_{\max }\left(\mathrm{CH}_{3} \mathrm{OH}+\mathrm{NaOMe}, \mathrm{nm}\right) 265,290,374$; $\lambda_{\max }\left(\mathrm{CH}_{3} \mathrm{OH}+\mathrm{NaOAc}, \mathrm{nm}\right) 270,315,385$; $\lambda_{\max }\left(\mathrm{CH}_{3} \mathrm{OH}+\mathrm{NaOAc} / \mathrm{H}_{3} \mathrm{BO}_{3}, \mathrm{~nm}\right) 272,316$, 385; $\lambda_{\max }\left(\mathrm{CH}_{3} \mathrm{OH}+\mathrm{AlCl}_{3}, \mathrm{~nm}\right) 252,295,372$; $\lambda_{\text {max }}\left(\mathrm{CH}_{3} \mathrm{OH}+\mathrm{AlCl}_{3} / \mathrm{HCl}, \mathrm{nm}\right) 251,294,370$. IR $v_{\max }(\mathrm{KBr}) \mathrm{cm}^{-1}: 3440(\mathrm{OH}), 1642(\mathrm{C}=\mathrm{O})$, $1600(\mathrm{C}=\mathrm{C}), 1255$ and 1100 (C-O-C stretching vibrations). EI-MS $(\mathrm{m} / \mathrm{z}) 260\left[\mathrm{M}^{+}\right] .{ }^{1} \mathrm{H}-\mathrm{NMR}$ $\left(500 \mathrm{MHz}, \mathrm{DMSO}-\mathrm{d}_{6}\right): \delta 13.34(1 \mathrm{H}, \mathrm{s}, \mathrm{OH}-$ C1), $7.46(1 \mathrm{H}, \mathrm{d}, \mathrm{J}=8.1 \mathrm{~Hz}, \mathrm{H}-8), 7.1(1 \mathrm{H}, \mathrm{d}$, $\mathrm{J}=8.1 \mathrm{~Hz}, \mathrm{H}-7), 6.48$ (d, J=1.4 Hz, H-4), 6.3 (d, J=1.4 Hz, H-2).

\section{1,3,6,7-tetrahydroxy-8-(3-methylbut-2-}

enyl) xanthone (compound 4, Fig. 1). $8 \mathrm{mg}$ $(0.08 \mathrm{mg} / \mathrm{g}$ callus fresh weight), yellow needles $\left(\mathrm{CH}_{3} \mathrm{OH}\right)$, mp 200-202 ${ }^{\circ}, \mathrm{R}_{\mathrm{f}}=0.44$ (system I). This compound showing an orange fluorescence under UV light was positive to $\mathrm{FeCl}_{3}$ test. UV: $\lambda_{\max }\left(\mathrm{CH}_{3} \mathrm{OH}, \mathrm{nm}\right) 242,258$, 313,$365 ; \lambda_{\max }\left(\mathrm{CH}_{3} \mathrm{OH}+\mathrm{NaOMe}, \mathrm{nm}\right) 243$, $269,321,400 ; \lambda_{\max }\left(\mathrm{CH}_{3} \mathrm{OH}+\mathrm{NaOAc}, \mathrm{nm}\right)$ $243, \quad 267, \quad 319, \quad 385 ; \quad \lambda_{\max }\left(\mathrm{CH}_{3} \mathrm{OH}+\right.$ $\left.\mathrm{NaOAc} / \mathrm{H}_{3} \mathrm{BO}_{3}, \mathrm{~nm}\right) 242,267,320,386 ; \lambda_{\max }$ $\left(\mathrm{CH}_{3} \mathrm{OH}+\mathrm{AlCl}_{3}, \mathrm{~nm}\right) 238,272,353,415 ; \lambda_{\max }$ $\left(\mathrm{CH}_{3} \mathrm{OH}+\mathrm{AlCl}_{3} / \mathrm{HCl}, \mathrm{nm}\right) 238,271,352,413$. IR $v_{\max }(\mathrm{KBr}) \mathrm{cm}^{-1}: 3470(\mathrm{OH}), 1640(\mathrm{C}=\mathrm{O})$, $1590(\mathrm{C}=\mathrm{C}), 1235$ and 1140 (C-O-C stretching vibrations). EI-MS $(\mathrm{m} / \mathrm{z}): 328\left[\mathrm{M}^{+}\right] .{ }^{1} \mathrm{H}-\mathrm{NMR}$ $\left(500 \mathrm{MHz}, \mathrm{DMSO}-\mathrm{d}_{6}\right): \delta 13.61(1 \mathrm{H}, \mathrm{s}, \mathrm{OH}-$ C1), 6.45 (s, H-5), 6.19 (d, J= 1.4 Hz, H-4), 
$6.12(\mathrm{~d}, \mathrm{~J}=1.4 \mathrm{~Hz}, \mathrm{H}-2), 5.25(\mathrm{t}, \mathrm{J}=6.3 \mathrm{~Hz},=$ $\mathrm{CH}-), 4.15\left(\mathrm{~d}, \mathrm{~J}=6.3 \mathrm{~Hz},-\mathrm{CH}_{2}-\right), 1.74$ and 1.65 $\left(6 \mathrm{H}, \mathrm{s}, \mathrm{CH}_{3}-14,15\right)$.

1,3,6,7-tetrahydroxy-2,8-di(3-methylbut-2enyl) xanthone ( $\gamma$-mangostin) (compound $\mathbf{5}$, Fig. 1). $4 \mathrm{mg}$ (0.04 mg/g callus fresh weight), yellow amorphous powder $\left(\mathrm{CH}_{3} \mathrm{OH}\right)$, mp 199$200^{\circ}, R_{\mathrm{f}}=0.51$ (system I). It gave an orange fluorescence under $\mathrm{UV}$ light and a positive $\mathrm{FeCl}_{3}$ test. UV: $\lambda_{\max }\left(\mathrm{CH}_{3} \mathrm{OH}, \mathrm{nm}\right) 243,260$, 318, 366; $\lambda_{\max }\left(\mathrm{CH}_{3} \mathrm{OH}+\mathrm{NaOMe}, \mathrm{nm}\right) 244$, 278, 344, 398; $\lambda_{\max }\left(\mathrm{CH}_{3} \mathrm{OH}+\mathrm{NaOAc}, \mathrm{nm}\right)$ $242, \quad 269, \quad 324, \quad 377 ; \quad \lambda_{\max } \quad\left(\mathrm{CH}_{3} \mathrm{OH}+\right.$
$\left.\mathrm{NaOAc} / \mathrm{H}_{3} \mathrm{BO}_{3}, \mathrm{~nm}\right) 243,270,324,377 ; \lambda_{\max }$ $\left(\mathrm{CH}_{3} \mathrm{OH}+\mathrm{AlCl}_{3}, \mathrm{~nm}\right) 241,272,359,420 ; \lambda_{\max }$ $\left(\mathrm{CH}_{3} \mathrm{OH}+\mathrm{AlCl}_{3} / \mathrm{HCl}, \mathrm{nm}\right) 241,273,358,418$. IR $v_{\max }(\mathrm{KBr}) \mathrm{cm}^{-1}: 3475(\mathrm{OH}), 1641(\mathrm{C}=\mathrm{O})$, $1610(\mathrm{C}=\mathrm{C}), 1285$ and 1100 (C-O-C stretching vibrations). EI-MS $(\mathrm{m} / \mathrm{z}): 396\left[\mathrm{M}^{+}\right] .{ }^{1} \mathrm{H}-\mathrm{NMR}$ $\left(500 \mathrm{MHz}, \mathrm{DMSO}_{\mathrm{d}}\right): \delta 13.92(1 \mathrm{H}, \mathrm{s}, \mathrm{OH}-$ C1), 6.79 (1H, s, H-5), 6.36 (1H, s, H-4), 5.30 $(1 \mathrm{H}, \mathrm{t}, \mathrm{J}=7.4 \mathrm{~Hz}, \mathrm{H}-12), 5.27(1 \mathrm{H}, \mathrm{t}, \mathrm{J}=6.9 \mathrm{~Hz}$, $\mathrm{H}-17), 4.20(2 \mathrm{H}, \mathrm{d}, \mathrm{J}=6.9 \mathrm{~Hz}, \mathrm{H}-16), 3.34(2 \mathrm{H}$, $\mathrm{d}, \mathrm{J}=7.4 \mathrm{~Hz}, \mathrm{H}-11), 1.83$ (3H, s, $\left.\mathrm{CH}_{3}-19\right), 1.78$ (3H, s, $\left.\mathrm{CH}_{3}-20\right), 1.64$ (6H, s, $\left.\mathrm{CH}_{3}-14,15\right)$.<smiles>[R]c1cc(O)c(C(=O)c2cc([R])c([R7])c([R])c2O)c(O)c1</smiles>

\begin{tabular}{|c|c|c|c|c|}
\hline Xanthone & R & R' $^{\prime}$ & R" $^{\prime}$ & R"' $^{\prime}$ \\
\hline $\mathbf{1}$ & H & H & H & OH \\
\hline $\mathbf{2}$ & OH & H & H & OH \\
\hline $\mathbf{3}$ & OH & OH & OH & H \\
\hline
\end{tabular}<smiles>CC(C)=CCc1c(O)cc(O)c(C(=O)c2c(C)cc(O)c(O)c2C=CC(C)C)c1O</smiles>

Fig. 1: Xanthones isolated from Hypericum gnidioides Seem. cell cultures. 


\section{RESULTS AND DISCUSSION}

Cell cultures of $H$. gnidioides Seem. grown in modified B5 medium accumulate a remarkable spectrum of secondary metabolites. They are isolated and identified as xanthones (1-5, Fig. 1) by UV, IR, mass and ${ }^{1} \mathrm{H}-\mathrm{NMR}$ spectroscopy, as well as co-chromatography (TLC and HPLC) with samples of reference xanthones.

The UV spectra of polyoxygenated xanthones vary according to their oxygenation pattern. ${ }^{18}$ This technique provides helpful information about the location of free hydroxyl groups by running the spectra in the presence of certain additives such as sodium methoxide $(\mathrm{NaOMe})$, sodium acetate $(\mathrm{NaOAc})$, sodium acetate/boric acid $\left(\mathrm{NaOAc} / \mathrm{H}_{3} \mathrm{BO}_{3}\right)$, aluminium chloride $\left(\mathrm{AlCl}_{3}\right)$ and aluminium chloride/hydrochloric acid $\left(\mathrm{AlCl}_{3} / \mathrm{HCl}\right)$. Sodium methoxide is a strong base can ionise hydroxyl groups at all positions of xanthone skeleton resulting in a significant alterations of the absorption spectrum. Sodium acetate being a weaker base ionise only the hydroxyl groups of enhanced acidity (C-3/C-6), which are activated by the para carbonyl function, causing bathochromic shift. In addition, it can ionise some other hydroxyl groups partially e.g. $\mathrm{C}-4$, resulting only in changes in absorption intensity and having no effect on the hydroxyl group at C-2. Aluminium chloride causes a bathochromic effect on C-1 hydroxyl group, in addition, it can detect ortho-hydroxyl system. Sodium acetate/boric acid can also detect ortho-hydroxyl system as $\mathrm{AlCl}_{3}$.

The compounds 1-5 were obviously phenolic since they gave a positive ferric chloride test and contained appropriate bands in their IR spectra.

The EI-MS spectrum of compound 1 showed a $\left[\mathbf{M}^{+}\right]$peak at $m / z 228$ corresponded to the molecular formula $\mathrm{C}_{13} \mathrm{H}_{8} \mathrm{O}_{4}$. Its $\mathrm{UV}$ spectrum revealed bathochromic shifts upon addition of sodium methoxide and aluminium chloride, but not with sodium acetate indicating the absence of hydroxyl groups at C-3 and C-6. The IR spectrum suggested the presence of hydroxyl group(s) $\left(3290 \mathrm{~cm}^{-1}\right)$ and a hydrogenbonded carbonyl $\left(1640 \mathrm{~cm}^{-1}\right)$. The ${ }^{1} \mathrm{H}-\mathrm{NMR}$ spectrum showed signals for ortho-coupled protons $(\delta 7.58, \mathrm{t}, \mathrm{J}=8.1 \mathrm{~Hz} ; 7.45, \mathrm{~d}, \mathrm{~J}=8.6$ $\mathrm{Hz})$, signal for meta-coupled proton $(\delta 7.7, \mathrm{~d}$,
$\mathrm{J}=2.2 \mathrm{~Hz})$ and signals for ortho and metacoupled protons $(\delta 7.40$ and $6.94, \mathrm{dd}, \mathrm{J}=8.1$ and $1.8 \mathrm{~Hz} ; 7.30$, dd, $\mathrm{J}=8.6$ and $2.2 \mathrm{~Hz}$ ). A low field singlet $(\delta 12.53)$ represents the 1-hydroxy group. ${ }^{19}$ The UV, IR, mass and ${ }^{1} \mathrm{H}-\mathrm{NMR}$ spectroscopic data of compound $\mathbf{1}$ were identical with those reported for 1,7dihydroxyxanthone. ${ }^{11,20}$

Compound 2 gave a $\left[\mathrm{M}^{+}\right]$peak at $\mathrm{m} / z 244$ in EI-mass spectrum consistent with the molecular formula $\mathrm{C}_{13} \mathrm{H}_{8} \mathrm{O}_{5}$. The UV spectrum exhibited bathochromic shifts upon addition of sodium acetate, aluminum chloride and sodium methoxide. The IR spectrum revealed a characteristic bands for the hydroxyl group(s) and a hydrogen-bonded carbonyl group at 3310 and $1640 \mathrm{~cm}^{-1}$ respectively. The ${ }^{1} \mathrm{H}-\mathrm{NMR}$ spectrum showed signal for ortho-coupled proton $(\delta 7.48, \mathrm{~d}, \mathrm{~J}=8.3 \mathrm{~Hz})$, signals for metacoupled protons $(\delta 7.41, \mathrm{~d}, \mathrm{~J}=2.3 ; 6.41$ and $6.21, \mathrm{~d}, \mathrm{~J}=2.1$ ) and signal for ortho and metacoupled proton $(\delta 7.22$, dd, $\mathrm{J}=8.3$ and $2.3 \mathrm{~Hz})$. A low field singlet $(\delta 12.71)$ represents the 1hydroxy group. ${ }^{19}$ The UV, IR, mass and ${ }^{1} \mathrm{H}-$ NMR spectroscopic data of compound $\mathbf{2}$ were in accordance with those published for 1,3,7trihydroxyxanthone. ${ }^{11,21,22}$

Compound 3 was also a xanthone. Its ${ }^{1} \mathrm{H}$ NMR spectrum contained signals for two pairs of aromatic protons, one ortho-coupled ( $\delta 7.46$ and $7.1, \mathrm{~d}, \mathrm{~J}=8.1 \mathrm{~Hz}$ ) and the other metacoupled $(\delta 6.48$ and $6.3, \mathrm{~d}, \mathrm{~J}=1.4 \mathrm{~Hz})$. A low field singlet $(\delta 13.34)$ represents the 1-hydroxyl group. ${ }^{19}$ Its UV spectrum revealed a bathochromic shifts upon addition of $\mathrm{NaOMe}$, $\mathrm{NaOAc}, \mathrm{NaOAc} / \mathrm{H}_{3} \mathrm{BO}_{3}, \mathrm{AlCl}_{3}$ and $\mathrm{AlCl}_{3} / \mathrm{HCl}$. The IR spectrum showed a characteristic bands for the hydroxyl group(s) and a hydrogenbonded carbonyl group at 3440 and $1642 \mathrm{~cm}^{-1}$ respectively. The mass spectrum showed a molecular ion peak at $\mathrm{m} / z \quad 260$ which corresponded to the molecular formula $\mathrm{C}_{13} \mathrm{H}_{8} \mathrm{O}_{6}$, revealing the presence of four hydroxyl groups. Comparison of the UV, IR, mass, ${ }^{1} \mathrm{H}-\mathrm{NMR}$ spectroscopic data with literature values established the identity of compound $\mathbf{3}$ as 1,3,5,6-tetrahydroxyxantone..$^{23,24}$

Classification of compound $\mathbf{4}$ as a xanthone on the basis of its UV spectrum implies that a $\mathrm{C}_{5}$-unit and four oxygen functions be added to the nucleus to reach a molecular weight of $328\left[\mathrm{M}^{+}\right]$consistent with 
the molecular formula $\mathrm{C}_{18} \mathrm{H}_{16} \mathrm{O}_{6}$. This is supported by bathochromic shifts upon addition of $\mathrm{NaOAc}, \quad \mathrm{NaOAc} / \mathrm{H}_{3} \mathrm{BO}_{3}, \mathrm{AlCl}_{3}$ and $\mathrm{AlCl}_{3} / \mathrm{HCl}$. The IR spectrum revealed two characteristic bands for the hydroxyl group(s) and a hydrogen-bonded carbonyl group at 3470 and $1640 \mathrm{~cm}^{-1}$ respectively. The ${ }^{1} \mathrm{H}-\mathrm{NMR}$ spectrum of compound 4 showed a low field singlet $(\delta$ 13.61) represents the 1-hydroxyl group $^{19}$ and signals for meta coupled protons $(\delta$ 6.19 and $6.12, \mathrm{~d}, \mathrm{~J}=1.4 \mathrm{~Hz}$ ). The $\mathrm{C}_{5}$-unit is a prenyl (3-methylbut-2-enyl) group showing two high-field three-proton signals and a vinylic proton signal at expected chemical shift values while the methylene group signal is at rather low field $(\delta$ 4.11). This indicates that it is situated at $\mathrm{C}-8$ of the xanthone nucleus i.e., in the peri position and, thus, subject to an anisotropic effect from the carbonyl group. The solitary aromatic proton in this ring also resonates at a $\delta$-value in agreement with its positioning at $\mathrm{C}-5$ rather than at $\mathrm{C}-8 .{ }^{25}$ The $\mathrm{UV}$, IR, mass and ${ }^{1} \mathrm{H}-\mathrm{NMR}$ spectroscopic data of compound 4 were identical with those reported for 1,3,6,7-tetrahydroxy-8-(3-methylbut-2-enyl) xanthone. $^{26,27}$

Compound 5 was also a xanthone. Its ${ }^{1} \mathrm{H}$ NMR spectrum showed a low field singlet $(\delta$ 13.92) characteristic for the 1-hydroxyl group ${ }^{19}$ and two aromatic protons one on each ring resonate at a $\delta$-values in agreement with their positioning at C-4 and C-5. The UV spectrum implies that two prenyl and four oxygen functions be added to the nucleus to reach a molecular weight of $396\left[\mathrm{M}^{+}\right]$consistent with the molecular formula $\mathrm{C}_{23} \mathrm{H}_{24} \mathrm{O}_{6}$. The IR spectrum showed two characteristic bands for the hydroxyl group(s) and a hydrogen-bonded carbonyl group at 3475 and $1641 \mathrm{~cm}^{-1}$ respectively. Matching the ${ }^{1} \mathrm{H}-\mathrm{NMR}$ and mass spectra of compounds 4 and 5 concluded that compound 5 has two prenyl groups. The UV, IR, mass and ${ }^{1} \mathrm{H}-\mathrm{NMR}$ spectroscopic data of compound 5 were identical with those reported for $\left(\gamma\right.$-mangostin). ${ }^{28,29}$

It is interesting to note that compounds 1-5 were found to have biological and pharmacological activities as mentioned before in the introduction part, consequently, this experiment from economic point of view provides a good conditions for large scale production of xanthones.
The occurrence of 1,7-dihydroxyxanthone in cell cultures of Hypericum gnidioides confirms its occurrence in cell cultures of Hypericum androsaemum which points to the biosynthetic involvement of a reductase eliminating the 3-hydroxy group. ${ }^{30}$

1,3,7-Trihydroxyxanthone is isolated for the first time from cell cultures of Hypericum species; its occurrence confirms the biosynthetic pathway of xanthones in Hypericum species. ${ }^{21,31}$

\section{Acknowledgement}

I would like to thank Prof. Dr. L. Beerhues (Institute for Pharmaceutical Biology, Technical University-Braunschweig, Germany) for providing reference xanthones and Dr. G. Eckhardt and Dr. W. Tomberg (Institute for Organic Chemistry, University of Bonn, Germany) for performing mass and ${ }^{1} \mathrm{H}-\mathrm{NMR}$ spectra, respectively.

\section{REFERENCES}

1- P. Arends, Tetrahedron Lett., 4893 (1969).

2- P. Helboe, Xanthone Studies, Dissertation, Royal Danish School of Pharmacy, Denmark (1973).

3- H. Bjorholm, The isolation and structural elucidation of the constituents of Hypericum maculatum, Dissertation, Royal Danish School of Pharmacy, Denmark (1978).

4- E. Ernst, Phytomedicine, 2, 67 (1995).

5- Y. Öztürk, S. Aydin, R. Beis, K. H. C. Baser and H. Berberoglu, Phytother. Res., 10, 700 (1996).

6- Y. Öztürk, Pharmacopsychiatry, 30 (Suppl. 2), 125 (1997).

7- B. M. Sundaram, C. Gopalakrishnan, S. Subramanian, D. Shankaranarayanan and L. Kameswaran, Planta Med., 48, 59 (1983).

8- F. S. Al-Jeboury and H. D. Locksley, Phytochemistry, 10, 603 (1971).

9- B. M. Sundaram, C. Gopalakrishnan and S. Subramanian, 1986. Arogya 12, 48-49. [Chem. Abstr. 105, 57798y (1986)].

10- C. Gopalakrishnan, D. Shankaranarayanan, S. K. Nazimudeen and $L$. Kameswaran, Ind. J. Pharmacol., 12, 181 (1980). 
11- C. N. Lin, M. I. Chung, S. J. Liou, T. H. Lee and J. P. Wang, J. Pharm. Pharmacol, 48, 532 (1996).

12- H. Minami,Y. Kinoshita, M. Kodama, T.Yoshizawa, M. Sugiura, K. Nakagawa and H. Tago, Phytochemistry, 36, 501 (1994).

13- S. Ghosal, K. Biswas and R. K. Chaudhuri, J. Pharm. Sci., 67, 721 (1978).

14- Chen, Shao-Xing, M. Wan and Loh BonnNee, Planta Med., 62, 381 (1996).

15- M. Abou-Shoer, F. E. Boettner, C. J. Chang and J. M. Cassady, Phytochemistry, 27: 2795 (1988).

16- O. L. Gamborg and D. E. Eveleigh, J. Biochem., 46, 417 (1968).

17- L. Beerhues and U. Berger, Planta, 197, 608 (1995).

18- M. Afzal, T. EL-Hassan and F. Al-Masad, Heterocycles, 12, 269 (1982).

19- P. Arends and P. Helboe, Acta Chem. Scand., 26, 4180 (1972).

20- T. Fujita, Da-you Liu, S. Ueda and Y. Takeda, Phytochemistry, 31, 3997 (1992).

21- S. Peter, W. Schmidt and L. Beerhues, Planta, 204, 64 (1998).

22- J. L. Wolfender, PhD thesis, University of Lausanne, Switzerland (1993).
23- P. K. Grover, G. D. Shah and R. C. Shah, Chem. Ind., (London), 62 (1955).

24- G. Sia, G. J. Bennett, L. J. Harrison and K. Sim, Phytochemistry, 38, 1521 (1995).

25- D. Barrachlough, A. D. Locksley, F. Scheinmann, M. T. Magalhaes and O. R. Gottlieb, J. Chem.Soc., B, 603 (1970).

26- N. Hanne and A. Peter, J. of Natural Products, 42, 301 (1979).

27- A. M. A. Abd El-Mawla, Biosynthesis of benzoic acids in cell cultures of Hypericum androsaemum L. and Centaurium erythraea RAFN, Dissertation, University of Bonn, Germany (2001).

28- K. Ishiguro, H. Fukumoto, M. Nakajima and K. Isoi, Phytochemistry, 33, 839 (1993).

29- M. Iinuma, H. Tosa, T. Tanaka, F. Asai, Y. Kobayashi, R. Shimano and K. Miyauchi, J. Pharm. Pharmacol., 48, 861 (1996).

30- W. Schmidt, A. M. A. Abd El-Mawla, J. Wolfender, K. Hostettmann and L. Beerhues, Planta Med., 66, 380 (2000).

31- W. Schmidt and L. Beerhues, FEBS Letters, 420, 143 (1997). 